\title{
Does Early ART Initiation is Better than Later ART Initiation in TB/HIV Co-infected Patients? A Retrospective Cohort Study
}

Tesfay Mehari Atey

Mekelle University

Fikermaryam Girma

Mekelle University

Kald Beshir Tuem

Mekelle University

Abadi Kahsu Gebre

Mekelle University

Hagos Gidey

Mekelle University

Mola Kahssay

Samera University

Hiluf Hindeya Gebreyesus

Mekelle University

Solomon Weldegebreal Asgedom

Mekelle University

Desilu Mahari Desta ( $\sim$ desiluma45@gmail.com )

Mekelle University https://orcid.org/0000-0003-0332-9517

\section{Research}

Keywords: Treatment outcome, early ART initiation, late ART initiation, TB/HIV co-infection

Posted Date: October 30th, 2020

DOl: https://doi.org/10.21203/rs.3.rs-15492/v2

License: (c) (i) This work is licensed under a Creative Commons Attribution 4.0 International License.

Read Full License 


\section{Abstract}

Background: The co-infection of TB/HIV poses a significant burden in the health care system of developing countries like Ethiopia. There are conflicting results on the preference of the time to initiate antiretroviral therapy (ART) and hence assessing the survival experience and treatment outcomes associated with ART initiation is crucial to settle the controversies. The study compared the treatment outcomes in early versus later ART initiation in TB/HIV co-infected patients.

Methods: A retrospective cohort study was conducted in Ayder Comprehensive Specialized Hospital and Mekelle Referral Hospital on 77 and 105 patients that started ART early and lately, respectively. An assumption for proportional hazard was met. Kaplan-Meier and life-table analyses were used to compare survival curves; and an independent samples t-test was used to compare means of the continuous variables between the two cohorts. Moreover, incidence per 100 persons-years was employed to crudely determine new morality rates, and Cox regression analysis was done to find out the effects of independent variables on the outcome variables.

Results: The mean survival time was 5.8 months after ART initiation. A 9.9 and 5.5 new incident mortality rates per 10,000 persons-years for the early and late ART initiation were observed, respectively. There was a statistically significant difference in mean CD4 ${ }^{+} T$ cells between early $(208.20 \pm 11.94$ cells $\left./ \mathrm{mm}^{3}\right)$ and late $\left(245.94 \pm 11.69\right.$ cells $\left./ \mathrm{mm}^{3}\right)$ ART initiators $\left(\mathrm{t}_{180}=-2.213, p<0.028\right)$. Additionally, late initiators had a better survival chance at all levels of time (Log Rank $c^{2}=5.56, p<0.018$ ) than early initiators. Having normal body mass index [adjusted hazard ratio [AHR $=0.263 ; 95 \%$ confidence interval [CI]: 0.089-0.778] and having a 'working' baseline functional status [AHR $=0.151 ; 95 \% \mathrm{Cl}: 0.054-0.427$ ] were found to be preventive factors from death. However, patients with $<250 \mathrm{CD} 4^{+} \mathrm{T}$ cells $/ \mathrm{mm}^{3}$ were more likely to die earlier [AHR=12.023; 95\%: 1.588-91.005] than their counterpart groups.

Conclusion: TB/HIV co-infected patients who had a CD4 count of below 250 cells/ul started ART regimen within two weeks of TB treatment initiation were found to have better survival outcomes than those who start ART beyond two weeks in the study settings. Moreover, female patients were more likely to die than males and, patients with the functional status of bedridden were more likely to die in contrast to working and ambulatory functional status. Moreover, body mass index, baseline functional status, and CD4 count were found to be independent predictors of mortality.

\section{Background}

Tuberculosis (TB) is an infectious disease caused by Mycobacterium tuberculosis [1] and results in either a latent infection or a progressive active disease [2]. Human Immune Deficiency Virus (HIV) is an infection that targets the immune system and the resulting immunodeficiency leads to increased susceptibility to a wide range of infections and diseases including TB [3]. The disease remains the most common risk factor for active TB especially among people 25 to 44 years of age [2]. 
The existence of active TB is highly prevalent in HIV patients [4]. TB is the leading opportunistic infection (OI) in HIV infected patients and the most common cause of mortality among TB/HIV co-infected patients that accounted for one-third of deaths worldwide [5]. HIV is driving the TB epidemic in many countries and this appears more serious in sub-Saharan Africa [4]. Co-infection has increased the risk of death, treatment failure, and relapse [6]. It was estimated that about 1.2 million people living with HIV had TB co-infection worldwide in 2015. Africa accounted for $75 \%$ of all deaths. Globally, people living with HIV are 19 times more likely to fall ill with TB than those without HIV [7].

Ethiopia is one of the 22 high burden countries and TB remained one of the leading communicable diseases causing mortality in the country. According to the 2014 world health organization (WHO) report, the prevalence and incidence of all forms of TB were 211 and 224 per 100,000 populations, respectively. Excluding HIV related death, TB mortality was estimated to be 32 per 100,000 population in 2013. Among estimated all new TB cases, $13 \%$ of them were HIV co-infected [8].

ART has proven to have a great impact on the survival of HIV-infected patients with TB $[5,9,10]$. It can be initiated simultaneously or soon after the initiation of TB treatment. However, ART is often deferred until the intensive phase of TB treatment is completed because of concern about the immune reconstitution inflammatory syndrome (IRIS) [11,12], a high pill burden, and overlapping side effects [13]. These challenges may result in interruption or discontinuation of treatment for the acquired immunodeficiency syndrome (AIDS) or TB, which can lead to drug resistance and potentially limit future therapeutic options $[14,15]$ but the disadvantages must be weighed against the risk of increased mortality early in the treatment of TB.

The current WHO guidelines recommend that ART should be initiated as soon as possible 'within the first 8 weeks' of starting TB treatment and 'within the first 2 weeks' for patients who have CD 4 cell counts less than 50 cells $/ \mathrm{mm}^{3}$ [16]. Furthermore, some factors likely determine the general outcome of the survival time of TB/HIV co-infected patients who start their ART treatment early and late after TB treatment. Concerns about early initiation of ART include a high pill burden, pharmacological interactions, overlapping toxicities, and the IRIS. Conversely, delayed initiation of ART may be associated with HIV disease progression and death. Even though different researches have conducted on TB/HIV co-infection there are controversies' on the timing of initiation of the ART regimen and there is no similar study conducted in the setting. Hence, considering its possible benefit to TB/HIV program planners, decisionmakers, and project implementers, this particular study emphasized the direct and indirect effects on the overall survival experience of TB/HIV co-infected patients in early and late ART therapy in Ayder Comprehensive Specialized Hospital (ACSH) and Mekelle Referral Hospital (MRH).

\section{Methods}

\section{Operational definitions}


An ART was deemed to be initiated early if the ART is started within 2 weeks of TB treatment initiation and later if the ART is started after 2 weeks of TB treatment initiation [18].

\section{Study Design, Period, and Area}

This retrospective cohort study was conducted at ART and TB clinics of ACSH and MGH, which are the two largest governmental health institutions found in Mekelle, Ethiopia. Inpatient and outpatient medical records, pre-ART registers, follow-up forms, anti-TB record forms, ART intake forms, treatment outcome, and patient cards, SmartCare ${ }^{\circledR}$ as well as TB Information System documents of the eligible patients were reviewed retrospectively from 6-Feb-2017 to 24-April-2017, for six years ranging from index period (3-Jan2012) until the occurrence of the outcome, date of administrative censoring, or 24-April-2017.

\section{Study population}

The study population was all TB/HIV co-infected individuals who received their primary care at the TB and ART clinics from the index period to the end of data collection. Cross-linking of TB clinics with ART clinics and crosschecking of the records were conducted to identify eligible patients. TB/HIV co-infected patients who had started their ART early were considered as cases whereas late initiators were considered as control groups. The source population was all TB/HIV co-infected patients who obtained services at TB and ART clinics of both hospitals.

\section{Eligibility Criteria}

TB/HIV co-infected individuals who received their primary care at the clinics were 15 years old, and older, and were diagnosed with TB at any time during pre-ART and/or ART follow-up since 3-Jan-2012 were included in the study. On the other hand, TB/HIV co-infected patients whose TB treatment was not initiated during the enrolment period; who were non-ART users; whose period (month and year) of starting ART and TB treatment was unknown; who were transferred to other health institution; who were lost and drop to follow-up; and with unknown/non-documented outcome variable were excluded from the study.

\section{Sample Size and Sampling Technique}

Kelsey samples size calculation method was employed in this study [17] [Appendix 1]. Accordingly, the sample $(n)$ and the continuity corrected sample $\left(n_{c}\right)$ were found to be 236 and 212 , respectively. On actual data collection, 182 patients were enrolled in this study with 77 patients considered as early ART initiators and 105 patients enrolled as late ART initiators (with a ratio of about 1.3). These patients were selected based on a convenient sampling procedure. This selection procedure is summarized in Figure 1.

\section{Data collection process}


Data abstraction format was prepared and pre-tested conducted in $5 \%$ of the sample size (9 patients). Amendments of the data collection tool were considered based on the pretest. The staff members who had good work experience in the ART and TB clinics were recruited as data collectors. One day training was given to the data collectors by the principal investigator. Supervision was done daily basis by the principal investigator to assure the completeness of the data.

\section{Data analysis and interpretation}

The data abstraction format was Kaplan-Meier analysis was used to estimate the hazard ratios for survival status among TB/HIV co-infected patients who started their ART early versus lately after TB treatment. The assumption for proportional hazard was assessed graphically by log minus log survival curve [Supplementary Figure] and by the time-dependent Cox-model, and the assumption was met.

Because of the retrospective nature of data collection, sensitively analysis was performed to evaluate confounding by indication and the effect of loss to follow-up. To address the confounding by indication, a propensity score analysis was performed. Using logistic regression analysis, the expected probability of starting ART was calculated for each member of the group using a full list of covariates and interactions; this probability was considered the propensity score for starting ART. Using this score, patients who were on early ART were matched with patients who were on late ART treatment in a one-to-one manner according to the propensity scores. After matching the number of patients, the continuous outcome variables between the matched pairs were then compared to ensure balance. In this propensity-matched cohort, the Kaplan-Meier analysis was repeated to estimate the survival status between the groups. An adjusted Cox proportional hazards model was used to examine the overall effect of early and late ART initiation on survival status. An independent samples t-test was also used to compare the mean of the continuous variables between the two groups. Moreover, incidence rates of mortality per 100 person-years (PYs) of follow-up was employed to crudely determine mortality rates. Cox regression analysis and marginal structural model (MSM) were employed to find out the effects of socio-demographics, clinical characteristics, and treatment categories on the outcome variable. In all of the analyses, significance testing was done using two-sided $p$-values and $95 \% \mathrm{Cl}$. A $p$-value $<0.05$ was considered statistically significant.

\section{Ethics approval and consent to participate}

The study was formally approved by the Ethical Review Board of College of Health Sciences, Mekelle University. A letter of support was obtained from the medical director's office of the hospitals. All results of this research were based on the use of secondary data and the data collection was performed retrospectively. Therefore, obtaining informed written consent form from the study participants was not applicable in this study but the study was conducted following with the ethical standards of the institutional and national research committee. The study also adhered to the declarations of Helsinki and STROBE guidelines. 


\section{Results}

Concerning the socio-demographic characteristics of the study participants, less than half (45\%) of them were in the age group of 30-39 years, followed by $40-49$ years (24\%). The majority of the patients were males and were residing in urban for both groups [Table 1].

As shown in Table 2, about half (47.3\%) of the patients were having extra-pulmonary TB during the TB diagnosis. Besides this, almost all of the patients were naïve to TB treatment, taking TDF/3TC/EFV and 2RHZE/4RH as their HIV and TB management, respectively.

The average weight and body mass index (BMI) (in absolute $\mathrm{kg}$ and $\mathrm{kg} / \mathrm{m}^{2}$, respectively) were increased by 9.72 and 3.00 over the six-year, interpreting into $20.3 \%$ and $17.5 \%$ increase from 2012 to 2017 , respectively [Figure 2].

The mean CD 4 cells for patients who had less than 200 cells per $\mathrm{mm}^{3}$ decreased by $73.5 \%$ from 2012 to 2017. On the contrary, the mean CD 4 cells increased by $120 \%$ and $1466.7 \%$ for the same period for patients with CD4 between 200 and 350 cells, and more than 350 cells per $\mathrm{mm}^{3}$, respectively. The CD $4^{+} T$ cells increased (by $181.42 \%$ ) over the past six years, with an average of 320.25 cells per $\mathrm{mm}^{3}$ in 2017 , up from a mean of $113.80 \mathrm{~mm}^{3}$ in 2012 [Figure 3].

Among the deaths, the mean survival time for patients whose outcome was registered as 'death' was found to be 5.8 months commencing from the TB treatment start date. In the crude Cox-regression analysis, sex, BMI, CD $4^{+} \mathrm{T}$ cells (in cells $/ \mathrm{mm}^{3}$ ), and the functional status at baseline were found to be statistically significant factors associated with death. Thus, male patients at any time during the study period were $63.5 \%$ [AHR $=0.365 ; 95 \% \mathrm{Cl}$ : $0.147-0.905$ ] less likely to die than female patients. Moreover, without adjustment of the factors, the difference in risk of death between participants with normal BMI and abnormal BMI remains statistically significant, with approximately a $72.7 \%$ decrease $[A H R=0.263$; $95 \% \mathrm{Cl}: 0.089-0.778$ ] in the risk of death among participants with normal BMI compared abnormal BMI. On the contrary, at any particular time, about twelve times [AHR=12.023; 95\%: 1.588-91.005] as many patients with $\mathrm{CD} 4^{+} \mathrm{T}$ cells $<250$ cells $/ \mathrm{mm}^{3}$ were experiencing death compared to CD $4^{+} \mathrm{T}$ cells ${ }^{3} 250$ cells $/ \mathrm{mm}^{3}$. Lastly, patients with 'working' functional status at baseline were $84.9 \%$ [AHR=0.151; 95\% Cl: 0.054-0.427] less likely to die at any time point during the study period than patients with 'bedridden' functional status at baseline [Table 3].

There was a statistically significant difference in mean $\mathrm{CD} 4^{+} \mathrm{T}$ cells between early and late ART initiators $\left(t_{180}=-2.213, p<0.028\right)$. The average CD4 count for early ART initiators (mean=208.196 cells $/ \mathrm{mm}^{3}$; $\mathrm{SEM}=11.943$ cell $/ \mathrm{mm}^{3}$ ) was 37.747 cells $/ \mathrm{mm}^{3}$ lower than the average CD4 count for late ART initiators (mean $=245.943$ cells $/ \mathrm{mm}^{3} ; \mathrm{SEM}=11.688 \mathrm{cells} / \mathrm{mm}^{3}$ ). However, a statistically significant difference was not observed in the mean BMI for the two groups [Table 4]. 
Another finding illustrated in this study was that patients with late ART initiation had a better survival chance than patients with early ART initiation at all levels of time $(p<0.018)$. The test of equality of survival distributions for the different levels of survival status showed Chi-Square results of 5.56, 6.07, and 6.08 for the Log Rank (Mantel-Cox) $(p<0.018)$, Breslow (Generalized Wilcoxon) $(p<0.014)$, and Tarone-Ware $(p<0.014)$ respectively [Figure 4].

\section{Discussions}

The mean survival time was 5.8 months and the incidence mortality rate was 9.9 per 10,000 PYs for early ART initiators compared to 5.5 new death rates per 10,000 persons-years for late ART initiators. There was also a statistically significant difference in mean CD4+ T cells between the cohorts and patients with late ART initiation had a better survival chance than patients with early ART initiation at all levels of time. Four randomized controlled trials have examined the question of the optimal timing of ART in TB/HIV coinfected patients. In 2010, the Starting Antiretroviral Therapy at Three Points in Tuberculosis (SAPiT trial) demonstrated no overall difference in the primary endpoint of AIDS-defining illness or death between the early integrated therapy arm (ART commenced < 4 weeks of TB treatment) and late integrated therapy arm (ART commenced < 4 weeks after completing intensive TB treatment) [19]. A second international multicenter randomized controlled trial, the AIDS Clinical Trials Group (ACTG 5221) study, reported that immediate ART (<2 weeks) did not reduce the primary endpoint of AIDS-defining illness or death compared with early ART (8 to 12 weeks) [18]. However, both studies found that in patients with baseline CD4 counts $<50$ cells $/ \mathrm{mm}^{3}$, early ART initiation was associated with a significant reduction in AIDS or death. A third randomized controlled trial, the [Cambodian Early versus Late Introduction of Antiretrovirals] CAMELIA trial conducted in Cambodia, reported improved survival in predominantly pulmonary TB patients initiating ART at 2 weeks compared with 8 weeks [20].

In contrast, a Vietnamese randomized controlled trial of immediate (within 7 days of TB treatment) versus deferred (after 8 weeks TB treatment) ART initiation in patients with HIV-associated TB meningitis showed no survival benefit, and an increase in severe adverse events, in the immediate ART arm [21]. Collectively, the results of these four trials suggest that ART should be started early in TB/HIV co-infected patients with advanced immunosuppression, apart from those with TB meningitis [22]. The finding of the present study, however, differs from the above studies. The result of this study showed that initiating ART after two weeks (later) of starting TB therapy significantly increase survival among TB/HIV co-infected patients with newly diagnosed TB and with mean CD4 ${ }^{+}$T-cell counts of about $130 \mathrm{cells} / \mathrm{mm}^{3} \mathrm{compared}$ with the initiation of ART before two weak (early). The difference of the current study from the previous findings could be explained by variation in the timing of ART initiation and study design. The high likelihood of drug-to-drug interaction, overlapping toxicities of TB and ART regimens, and the higher prevalence of immune reconstitution inflammatory syndrome (IRIS) during early initiation might be the contributing factors for the increased mortality.

Another plausible explanation for this discrepancy could be the cut-off point used in this study (two weeks), unlike the aforementioned trials that used different classification systems of ART initiation. This 
difference in the timing of ART initiation may affect the outcome of this study and may attribute to the differences observed in the present study and the other findings. The late ART initiation is too delayed in the previous studies, compared to the current study, and hence the patients may have a greater deterioration in their immunity in these studies and maybe a reason for the greater mortality.

The interactions between rifampin and the Non-nucleoside reverse transcriptase inhibitors (NNRTIs) are particularly important because NNRTIs are recommended as components of initial ART in countries with a high burden of HIV infection [23]. The concentrations of all of the available NNRTIs are significantly reduced because of CYP2B6 and CYP3A4 induction by rifampin [24]. The effect of rifampin on nevirapine concentrations is greater than its effect on efavirenz concentrations. Reductions of $20 \%-55 \%$ in nevirapine concentrations have been reported $[25,26]$, with a greater proportion of co-treated patients having trough levels of nevirapine below the target ranges $[25,27,28]$. Concomitant rifampin treatment results in reductions of $\sim 20 \%-25 \%$ in efavirenz peak and trough concentrations [29,30]. Among patients not receiving TB treatment, lower trough concentrations of efavirenz are associated with an increased risk of virological failure and selection of drug-resistant viral strains [31,32]. This drug interaction may be one of the causes that increase mortality at early ART initiation.

Most of the adverse effects due to the TB treatment and ART occurs within the first months of therapy [33]. HIV-infected patients receiving TB treatment commonly experience drug toxicity [33,34]. Most studies suggest that adverse events are more common among HIV-infected patients than among HIVuninfected patients being treated for TB. For example, a retrospective study of patients treated for TB in Canada found that HIV-infected patients were 3.8 times more likely to experience a significant drugrelated adverse event (defined as one resulting in hospitalization or in modification or discontinuation of treatment) [35]. Thus, due to overlapping toxicities of TB treatment and ART occur frequently, pushing discontinuation of therapy and increasing the risk of non-adherence. This is may also be one of the causes of increased mortality among patients with early ART initiation.

Paradoxically, IRIS occurs within 6 weeks of the initiation of ART but it has been reported to occur many months after the commencement of ART [36,37]. Data from retrospective and observational studies indicated that TB-associated IRIS occurs in approximately $11 \%$ to $71.4 \%$ of TB/HIV co-infected patients starting ART [38]. Reports of high IRIS rates from various settings is a key reason for delaying the initiation of ART in patients receiving TB treatment $[17,18,20]$. This is maybe also another reason for the higher death during early ART initiation.

In this study, the majority of TB/HIV co-infected patients had a CD4 ${ }^{+} \mathrm{T}$ cell count of less than 250 cells $/ \mathrm{mm}^{3}$. Most TB infections had occurred in those whose CD $4^{+}$cell count was $<250 \mathrm{cell} / \mathrm{mm}^{3}$. About twelve times as many patients with $\mathrm{CD} 4^{+} \mathrm{T}$ cells $<250 \mathrm{cells} / \mathrm{mm}^{3}$ were experiencing death compared to $\mathrm{CD} 4^{+} \mathrm{T}_{\text {cells }}{ }^{3} 250$ cells $/ \mathrm{mm}^{3}$. These findings revealed that mortality upsurges as $\mathrm{CD} 4^{+} \mathrm{T}$ cells count decreases because the TB/HIV co-infection leads to severe immune suppression. Co-infection is associated with lower $\mathrm{CD} 4^{+} \mathrm{T}$ count than those with HIV alone, which could translate into an increased morbidity and progression of HIV to AIDS. Several other studies are consistent with this finding and they 
also pointed to the fact that $\mathrm{CD} 4^{+} \mathrm{T}$ cell count is lower among co-infected patients as compared to HIV infected alone and severe immune suppression is seen in those with $\mathrm{CD} 4^{+} \mathrm{T}$ cell count below 200 cells $/ \mathrm{mm}^{3}[39,40]$. Institutional based cross-sectional study conducted in Ethiopia on the magnitude and correlates of TB among HIV patients found that $79.5 \%$ of TB infection occurred in low CD4 level $(<200$ cells $/ \mathrm{mm}^{3}$ ), which could translate into increased morbidity, the progression of HIV to AIDS, and mortality [41].

Patients with 'working' baseline functional status were having an $84.9 \%$ of protection from death than patients with 'bedridden' baseline functional status, in which the former patients may have a better immunity status [42] and the later patients may present with an advance immunocompromised state and with many opportunistic infections.

The study has certain limitations. The investigators' rely on the record-keeping of others, which has an effect in accurate comparison of the exposure and outcome. The investigators have also less control over variables including over exposure and outcome variables.

\section{Conclusions}

TB/HIV co-infected patients who had a CD4 count of below 250 cells/ul started ART regimen within two weeks of TB treatment initiation were found to have better survival outcomes than those who start ART beyond two weeks in the study settings. Moreover, female patients were more likely to die than males and, patients with the functional status of bedridden were more likely to die in contrast to working and ambulatory functional status. Hence, multiple efforts should be in place for patients with these predictors. These findings call for greater research attention in TB/HIV co-infected patients and strengthening efforts in managing these patients.

\section{List Of Abbreviations}

ACSH=Ayder Comprehensive Specialized Hospital; AHR=Adjusted hazard ratio; AIDS Clinical Trials Group (ACTG); AIDS=Acquired immune deficiency syndrome; $A R T=$ Antiretroviral Treatment; BMI=Body mass index; CAMELIA=Cambodian Early versus Late Introduction of Antiretrovirals; CD4=Cluster of differentiation 4; $\mathrm{CHR}=$ Crude hazard ratio; $\mathrm{Cl}=$ Confidence interval; $\mathrm{CPT}=$ Cotrimoxazole Preventive Treatment; DOT= Directly observed therapy; HAART = Highly active antiretroviral therapy; HIV=Human Immune deficiency Virus; IRIS=Immune reconstitution inflammatory syndrome; MR=Mortality rates; Ol=Opportunistic infection; OR=Odds ratios; Person-years (PYs); PI=Protease Inhibitor; SAPiT=Starting Antiretroviral Therapy at Three Points in Tuberculosis; SD=Standard deviation; SEM=Standard error of mean; SPSS=Statistical Package for Social Sciences; TB=Tuberculosis; WHO=World Health Organization.

\section{Declarations}

\section{Consent to publish}


Not applicable.

\section{Availability of data and materials}

The datasets supporting the conclusions of the study are included in the article. Any additional data will be available on request.

\section{Competing interests}

The authors declare that they have no competing interests.

\section{Funding}

The study was not supported by any funding agent.

\section{Authors' Contributions}

TMA and FG were involved in the conception and design of the study, developed data collection tools, supervised data collection, analyzed data, and wrote the manuscript. SWA, KBT, AKG, HG, MK, HHG, and DMD involved in the writing, and editing of the manuscript. All authors read and approved the final manuscript.

\section{Acknowledgments}

We thank the management of Ayder Comprehensive Specialized Hospital and Mekelle General Hospital for invaluable assistance in conducting the study. We also thank study participants, data collectors and other staff members for their assistance with this study.

\section{References}

1. Ethiopian Federal Ministry of Health (FMOH). Guidelines For Clinical and Programmatic Management of TB, TB/HIV and Leprosy in Ethiopia. 5th Edition. Addis Ababa, Ethiopia: FMHACA, 2013. pp. 3-8.

2. DiPiro JT, Talbert RL, Yee GC, Matzke GR, Wells BG, Posey LM. Pharmacotherapy: A Pathophysiologic Approach. $9^{\text {th }}$ New York, USA: McGraw-Hill Education, 2014. pp. 3927.

3. Food, Medicine and Health Care Administration and Control Authority (FMHACA). Standard Treatment Guidelines For General Hospital. $3^{\text {rd }}$ Addis Ababa, Ethiopia: FMHACA, 2014. pp. 108.

4. Sileshi B, Deyessa N, Girma B, Melese M, Suarez P. Predictors of mortality among TB-HIV Co-infected patients being treated for tuberculosis in Northwest Ethiopia: a retrospective cohort study. BMC Infect Dis. 2013;13:297.

5. Manosuthi W, Chottanapand S, Thongyen S, Chaovavanich A, Sungkanuparph S. Survival rate and risk factors of mortality among HIV/tuberculosis-coinfected patients with and without antiretroviral therapy. J Acquir Immune Defic Syndr. 2006;1;43:42- 
6. Khan FA, Minion J, Pai M, Royce S, Burman W, Harries AD, et al. Treatment of active tuberculosis in HIV co-infected patients: a systematic review and meta-analysis. Clin Infect Dis. 2010;50:1288-99.

7. World Health Organization (WHO). TB/HIV fact sheets. Available at:

who.int/tb/challenges/hiv/factsheets/en/. Accessed on June 15, 2017.

8. World Health Organization (WHO). Ethiopia | Tuberculosis. Available at:

afro.who.int/en/ethiopia/country-programmes/topics/4481-tuberculosis.html. Accessed on June 15, 2017.

9. Zhou J, Elliott J, Li PC, Lim PL, Kiertiburanakul S, Kumarasamy N, et al. Risk and prognostic significance of tuberculosis in patients from the treat Asia HIV observational database. BMC Infect Dis. $2009 ; 9: 46$.

10. Sungkanuparph S, Manosuthi W, Kiertiburanakul S, Vibhagool A. Initiation of antiretroviral therapy in advanced AIDS with active tuberculosis: clinical experiences from Thailand. J Infect. 2006;52:18894.

11. Fishman JE, Saraf-Lavi E, Narita M, Hollender ES, Ramsinghani R, Ashkin D. Pulmonary tuberculosis in AIDS participants: transient chest radiographic worsening after initiation of antiretroviral therapy. AJR Am J Roentgenol. 2000;174:43-9.

12. Chien JW, Johnson JL. Paradoxical reactions in HIV and pulmonary TB. Chest. 1998;114:933-6.

13. Girardi E, Palmieri F, Cingolani A, Ammassari A, Petrosillo N, Gillini L, et al. Changing clinical presentation and survival in HIV-associated tuberculosis after highly active antiretroviral therapy. J Acquir Immune Defic Syndr. 2001;26:326-31.

14. Lalloo UG. Efavirenz and nevirapine interactions with rifampicin: resolving the dilemmas? Clin Infect Dis. 2009;48:1760-2.

15. Cohen K, Grant A, Dandara C, Mcllleron HM, Pemba L, Fielding K, et al. Effect of rifampicin-based antitubercular therapy and the cytochrome P450 2B6 516G>T polymorphism on efavirenz concentrations in adults in South Africa. Antivir Ther. 2009;14:687-95.

16. World Health Organization (WHO). Consolidated guidelines on the use of antiretroviral drugs for treating and preventing HIV infection: Recommendations for a public health approach. Available at: http://www.who.int/hiv/pub/ guidelines/arv2013/. Accessed on June 16, 2017.

17. Sullivan KM, Soe MM. Sample Size for an Unmatched Case-Control Study and Cohort Study, 2007.

18. Havlir DV, Kendall MA, Ive P, Kumwenda J, Swindells S, Qasba SS, et al. AIDS Clinical Trials Group Study A5221. N Engl J Med. 2011;365:1482-

19. Abdool Karim SS, Nwaidoo K, Grobler A. Starting antiretroviral therapy at three point in tuberculosis (SAPIT). N Engl J Med. 2010;362:697-706.

20. Blanc FX, Sok T, Laureillard D, Borand L, Rekacewicz C, Nerrienet E, et al. Earlier versus later start of antiretroviral therapy in HIV-infected adults with tuberculosis. N Engl J Med. 2011; 365:1471-81.

21. Török ME, Yen NT, Chau TT, Mai NT, Phu NH, Mai PP, et al. Timing of initiation of antiretroviral therapy in human immunodeficiency virus (HIV)-associated tuberculous meningitis. Clin Infect Dis. 
2011;52:1374-83.

22. Török ME, Farrar JJ. When to start antiretroviral therapy in HIV-associated tuberculosis. N Engl J Med. 2011;365:1538-40.

23. World Health Organization (WHO). Scaling up antiretroviral therapy in resource-limited settings: treatment guidelines for a public health approach. 2003 revision. Geneva: WHO, 2004.

24. Borin MT, Chambers JH, Carel BJ, Gagnon S, Freimuth WW Mcllleron, et al. Phar macokinetic study of the interaction between rifampin and delavirdine mesylate. Clin Pharmacol Ther. 1997;61:544-53.

25. Autar RS, Wit F, Sankote J, et al. Nevirapine plasma concentrations in the presence of rifampicin (HIVNAT 025) [abstract 21]. In: Program and abstracts of the 6th International Workshop on Clinical Pharmacology of HIV Therapy (Quebec). Utrecht: Virology Education, 2005. pp. 16.

26. Ribera E, Pou L, Lopez RM, Crespo M, Falco V, Ocaña I, et al. Pharmacokinetic interaction between nevirapine and rifampicin in HIV-infected patients with tuberculosis. J Acquir Immune Defic Syndr. $2001 ; 28: 450-3$.

27. Kappelhoff BS, Crommentuyn KML, De Maat MMR, Mulder JW, Huitema ADR, Beijnen JH. Practical guidelines to interpret plasma concentrations of antiretroviral drugs. Clin Pharmacokinet. 2004;43:845-53.

28. Cohen K, Van Cutsem G, Boulle A, et al. The nucleoside reverse transcriptase inhibitors and rifampicin. In: Program and abstracts of the 39th Congress of the South African Pharmacology Society (Cape Town). Potchefstroom. 2005. pp. 22.

29. Benedek IH, Joshi A, Fiske WD, et al. Pharmacokinetic interaction between efavirenz and rifampin in healthy volunteers [abstract 42280]. In: Program and abstracts of the 12th World AIDS Conference (Geneva). Geneva: International AIDS Society, 1998.

30. Lo'pez-Corte's LF, Ruiz-Valderas R, Viciana P, Alarcón-González A, Gómez-Mateos J, León-Jimenez E, et al. Pharmacokinetic interactions between efavirenz and rifampicin in HIV-infected patients with tuberculosis. Clin Pharmacokinet. 2002;41:681-90.

31. Marzolini C, Telenti A, Decosterd LA, Greub G, Biollaz J, Buclin T. Efavirenz plasma levels can predict treatment failure and central nervous system side effects in HIV-1-infected patients. AIDS. 2001;15:71-5.

32. Brundage RC, Yong FH, Fenton T, Spector SA, Starr SE, Fletcher CV. Intrapatient variability of efavirenz concentrations as a predictor of virologic response to antiretroviral therapy. Antimicrob Agents Chemother. 2004;48:979-84.

33. Dean GL, Edwards SG, Ives NJ, Matthews G, Fox EF, Navaratne L, et al. Treatment of tuberculosis in HIV-infected persons in the era of highly active antiretroviral therapy. AIDS. 2002;16:75-83.

34. Patel A, Patel K, Patel J, Shah N, Patel B, Rani S. Safety and antiretroviral effectiveness of concomitant use of rifampicin and efavirenz for antiretroviral-naive patients in India who are coinfected with tuberculosis and HIV-1. J Acquir Immune Defic Syndr. 2004;37:1166-9.

35. Yee D, Valiquette C, Pelletier M, Parisien I, Rocher I, Menzies D. Incidence of serious side effects from first-line antituberculosis drugs among patients treated for active tuberculosis. Am J Respir Crit Care 
Med. 2003;167:1472-7.

36. Breton G, Duval X, Estellat C, Poaletti X, Bonnet D, Mvondo Mvondo D, et al. Determinants of immune reconstitution inflammatory syndrome in HIV type 1-infected patients with tuberculosis after initiation of antiretroviral therapy. Clin Infect Dis. 2004;39:1709-12.

37. Narita M, Ashkin D, Hollender ES, Pitchenik AE. Paradoxical worsening of tuberculosis following antiretroviral therapy in patients with AIDS. Am J Respir Crit Care Med. 1998;158:157-61.

38. Weiner M, Benator D, Burman W, Peloquin CA, Khan A, Vernon A, et al. Association between acquired rifamycin resistance and the pharmacokinetics of rifabutin and isoniazid among patients with HIV and tuberculosis. Clin Infect Dis. 2005;40:1481-91.

39. Kamath R, Sharma V, Pattanshetty S, Hegde MB, Chandrasekaran V. HIV-TB coinfection: Clinicoepidemiological determinants at an antiretroviral therapy center in Southern India. Lung India. 2013;30:302-

40. Belay A, Alamrew Z, Berie Y, Tegegne B, Tiruneh G, Feleke A. Magnitude and correlates of tuberculosis among HIV patients at Felege Hiwot Referral Hospital, Bahir Dar city, Northwest Ethiopia. J Clin Med Res. 2013;2:77-

41. Franke MF, Robins JM, Mugabo J, Kaigamba F, Cain LE, Fleming JG, et al. Effectiveness of early antiretroviral therapy initiation to improve survival among HIV-infected adults with tuberculosis: a retrospective cohort study. PLoS Medicine. 2011; 8:e1001029.

42. Pedersen BK, Hoffman-Goetz L. Exercise and the immune system: regulation, integration, and adaptation. Physiological reviews. 2000;80:1055-

\section{Tables}

Table 1. Socio-demographic characteristics of TB/HIV co-infected patients in two governmental hospitals of Mekelle, Ethiopia, 2012-2017. 


\begin{tabular}{|c|c|c|c|c|}
\hline \multicolumn{2}{|l|}{ Variables } & \multicolumn{2}{|c|}{$\begin{array}{l}\text { Time difference between TB and ART } \\
\text { initiation }\end{array}$} & \multirow[t]{3}{*}{$\begin{array}{l}p- \\
\text { value }\end{array}$} \\
\hline & & Early ART initiation & Late ART initiation & \\
\hline & & $\mathrm{N}(\%)$ & $\mathrm{N}(\%)$ & \\
\hline \multirow[t]{2}{*}{ Sex } & Male & $45(43.3)$ & $59(56.7)$ & 0.762 \\
\hline & Female & $32(41.0)$ & $46(59.0)$ & \\
\hline \multirow[t]{2}{*}{ Residency } & Rural & $10(50.0)$ & $10(50.0)$ & 0.460 \\
\hline & Urban & $67(41.4)$ & $95(58.6)$ & \\
\hline \multirow{4}{*}{$\begin{array}{l}\text { Age in years (mean } \pm \text { SD, } 37.3 \pm \\
9.3 \text { ) }\end{array}$} & $<30$ & $13(36.1)$ & $23(63.9)$ & 0.847 \\
\hline & $30-39$ & $36(44.4)$ & $45(55.6)$ & \\
\hline & $40-49$ & $18(41.9)$ & $25(58.1)$ & \\
\hline & $\geq 50$ & $10(45.5)$ & $12(54.5)$ & \\
\hline
\end{tabular}

ART: Antiretroviral therapy; SD: Standard deviation; TB: tuberculosis

Table 2. Status and classification of TB at diagnosis stage, type of ART, and TB treatment regimen among TB/HIV co-infected patients in two governmental hospitals of Mekelle, Ethiopia, 2012-2017.

\begin{tabular}{|ll|}
\hline Variables & \multicolumn{1}{c|}{ Frequency (\%) } \\
\hline \multicolumn{2}{|l|}{ Status and classification of TB at the diagnosis stage } \\
\hline Extra pulmonary & $86(47.3)$ \\
\hline Smear negative & $43(23.6)$ \\
\hline Smear positive & $53(29.1)$ \\
\hline Retreatment & $3(1.6)$ \\
\hline New & $179(98.4)$ \\
\hline Type of ART treatment regimen & \\
\hline AZT + 3TC + EFV & $4(2.2)$ \\
\hline TDF + 3 TC + EFV & $178(97.8)$ \\
\hline Type of TB treatment regimen & \\
\hline 2 RHZE/10RH & $5(2.7)$ \\
\hline 2RHZES/RHZE/5RHE & $3(1.6)$ \\
\hline 2RHZE/4RH & $174(95.6)$ \\
\hline
\end{tabular}




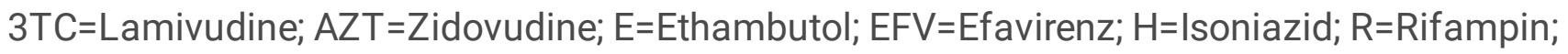

$S=S t r e p t o m y c i n ; T D F=T e n o f o v i r ; Z=P y r a z i n a m i d e$

Table 3. Factors associated with survival status among TB/HIV co-infected patients in two governmental hospitals of Mekelle, Ethiopia, 2012-2017.

\begin{tabular}{|c|c|c|c|c|c|c|c|}
\hline \multirow[t]{2}{*}{ Variable } & & \multicolumn{2}{|c|}{ Survival status } & \multirow[t]{2}{*}{$\mathrm{CHR}[95 \% \mathrm{Cl}]$} & \multirow{2}{*}{$\begin{array}{l}p- \\
\text { value }\end{array}$} & \multirow{2}{*}{$\begin{array}{l}\mathrm{AHR}[95 \% \\
\mathrm{Cl}]\end{array}$} & \multirow{2}{*}{$\begin{array}{c}p- \\
\text { value }\end{array}$} \\
\hline & & $\begin{array}{l}\text { Alive, } \\
\text { n (\%) }\end{array}$ & $\begin{array}{l}\text { Dead, } \\
\mathrm{n}(\%)\end{array}$ & & & & \\
\hline \multirow[t]{2}{*}{ Sex } & Male & $\begin{array}{l}97 \\
(93.3)\end{array}$ & $\begin{array}{l}7 \\
(6.7)\end{array}$ & $\begin{array}{l}0.334 \\
{[0.136-} \\
0.819]\end{array}$ & $0.017 *$ & $\begin{array}{l}0.365 \\
{[0.147-} \\
0.905]\end{array}$ & $0.030 *$ \\
\hline & Female & $\begin{array}{l}63 \\
(80.8)\end{array}$ & $\begin{array}{l}15 \\
(19.2)\end{array}$ & 1.00 & - & 1.00 & - \\
\hline \multirow[t]{2}{*}{$\begin{array}{l}\text { Body mass } \\
\text { index (BMI) }\end{array}$} & $\begin{array}{l}\text { Normal } \\
\text { BMI }\end{array}$ & $\begin{array}{l}76 \\
(95.0)\end{array}$ & $\begin{array}{l}4 \\
(5.0)\end{array}$ & $\begin{array}{l}0.263 \\
{[0.089-} \\
0.778]\end{array}$ & $0.016^{*}$ & $\begin{array}{l}0.364 \\
{[0.118-} \\
1.125]\end{array}$ & 0.079 \\
\hline & $\begin{array}{l}\text { Abnormal } \\
\text { BMI }\end{array}$ & $\begin{array}{l}84 \\
(82.4)\end{array}$ & $\begin{array}{l}18 \\
(17.6)\end{array}$ & 1.00 & - & 1.00 & - \\
\hline \multirow[t]{2}{*}{$\begin{array}{l}\text { CD4+ T cells } \\
\left.\text { (per } \mathrm{mm}^{3}\right)\end{array}$} & $<250$ & $\begin{array}{l}99 \\
(82.5)\end{array}$ & $\begin{array}{l}21 \\
(17.5)\end{array}$ & $\begin{array}{l}12.500 \\
{[1.679-} \\
93.060]\end{array}$ & $0.014 *$ & $\begin{array}{l}12.023 \\
{[1.588-} \\
91.005]\end{array}$ & $0.016 *$ \\
\hline & ${ }^{3} 250$ & $\begin{array}{l}61 \\
(98.4)\end{array}$ & $\begin{array}{l}1 \\
(1.6)\end{array}$ & 1.00 & - & 1.00 & - \\
\hline \multirow[t]{3}{*}{$\begin{array}{l}\text { Functional } \\
\text { status }\end{array}$} & Working & $\begin{array}{l}75 \\
(96.2)\end{array}$ & $\begin{array}{l}3 \\
(3.8)\end{array}$ & $\begin{array}{l}0.070 \\
{[0.020-} \\
0.244]\end{array}$ & 0.001 & $\begin{array}{l}0.146 \\
{[0.039-} \\
0.541]\end{array}$ & $0.004 *$ \\
\hline & Ambulatory & $\begin{array}{l}64 \\
(92.8)\end{array}$ & $\begin{array}{l}5 \\
(7.2)\end{array}$ & $\begin{array}{l}0.136 \\
{[0.049-} \\
0.380]\end{array}$ & 0.001 & $\begin{array}{l}0.151 \\
{[0.054-} \\
0.427]\end{array}$ & $0.001^{*}$ \\
\hline & Bedridden & $\begin{array}{l}21 \\
(60.0)\end{array}$ & $\begin{array}{l}14 \\
(40.0)\end{array}$ & 1.00 & - & 1.00 & - \\
\hline
\end{tabular}

Abbreviations: $\mathrm{AHR}=$ Adjusted hazard ratio; $\mathrm{CD} 4$ = Cluster of differentiation; $\mathrm{Cl}=$ Confidence interval; $\mathrm{CHR}=$ Crude hazard ratio, $\mathrm{BMl}=$ Body mass index,

*Statistically significant at $p<0.05$

Table 4. Mean values of CD4 and BMI by the status of ART initiation among TB/HIV co- infected patients in two governmental hospitals of Mekelle, Ethiopia, 2012-2017. 


\begin{tabular}{|c|c|c|c|c|c|c|}
\hline Variable & Status & Mean & $\mathrm{T}$ & Df & $\begin{array}{l}\text { p-value } \\
\text { (two- } \\
\text { tailed) }\end{array}$ & $\begin{array}{l}\text { Mean } \\
\text { Difference } \\
\text { [95\% Cl] }\end{array}$ \\
\hline \multirow[t]{2}{*}{ Average BMI $\left(\mathrm{kg} / \mathrm{m}^{2}\right)$} & $\begin{array}{l}\text { Early ART } \\
\text { initiation }\end{array}$ & 18.753 & 0.828 & 180 & 0.409 & $\begin{array}{l}0.335[-0.464- \\
1.134]\end{array}$ \\
\hline & $\begin{array}{l}\text { Late ART } \\
\text { initiation }\end{array}$ & 18.418 & & & & \\
\hline \multirow[t]{2}{*}{$\begin{array}{l}\text { Average } \mathrm{CD} 4^{+} \mathrm{T} \text { cells } \\
\left(\text { cells } / \mathrm{mm}^{3}\right)\end{array}$} & $\begin{array}{l}\text { Early ART } \\
\text { initiation }\end{array}$ & 208.196 & -2.213 & 180 & 0.028 & $\begin{array}{l}-37.747 \\
{[-71.406-} \\
-4.088]\end{array}$ \\
\hline & $\begin{array}{l}\text { Late ART } \\
\text { initiation }\end{array}$ & 245.943 & & & & \\
\hline
\end{tabular}

Abbreviation: $\mathrm{BMI}=$ Body mass index; $\mathrm{CD} 4+\mathrm{T}$ cells=Cluster of Differentiation 4 positive T-lymphocyte cells

Figures 
Total number of TB/HIV co-infected patients $[\sim \mathrm{n}=2245]$

Total number of patietns with missing medical records, taking ART before the index year and with unknown TB and ART initaition time $[\sim \mathrm{n}=901]$

Total number of TB/HIV coinfected patients not taking ART

$$
[\sim \mathrm{n}=23]
$$

Total number of TB/HIV co-infected patients taking ART $[\sim \mathrm{n}=1321]$

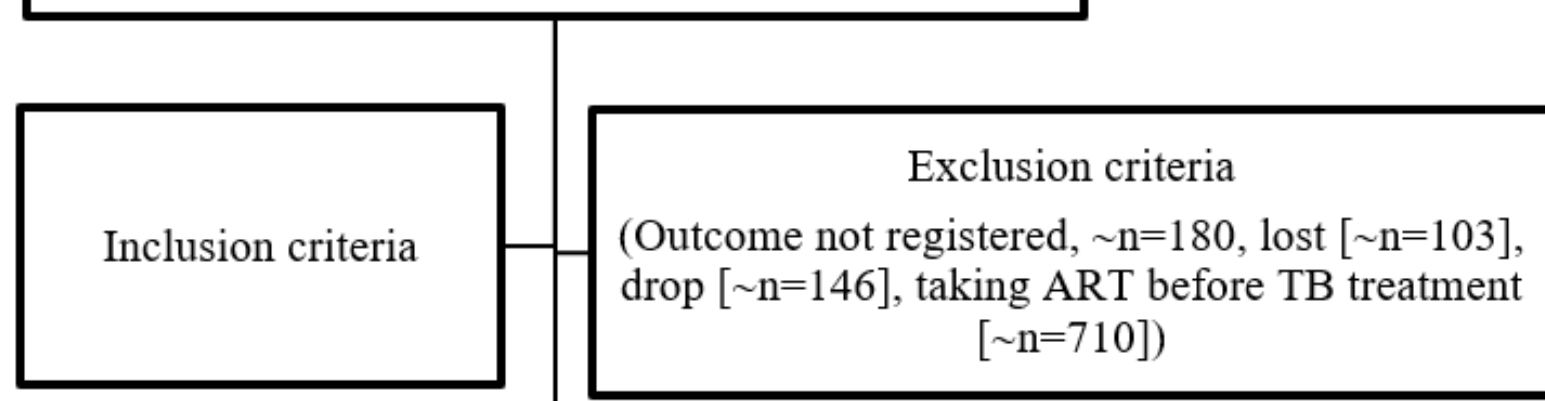

Cases $[\mathrm{n}=77]$

Controls $[\mathrm{n}=105]$

Figure 1

A diagram that shows eligible patients' selection process. 


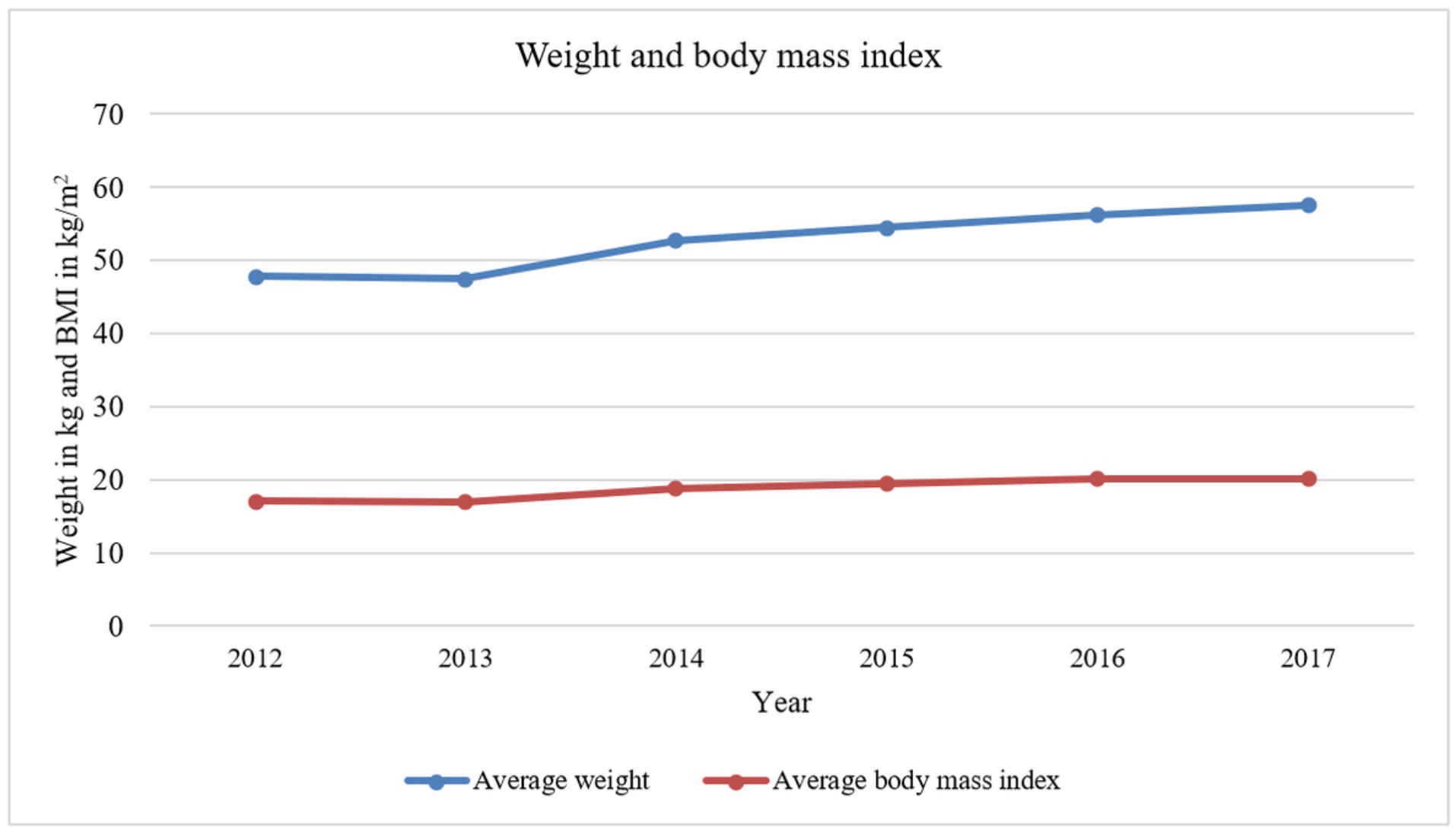

\section{Figure 2}

Trend of weight and body mass index among TB/HIV co-infected patients in two governmental hospitals of Mekelle, Ethiopia, 2012-2017. 


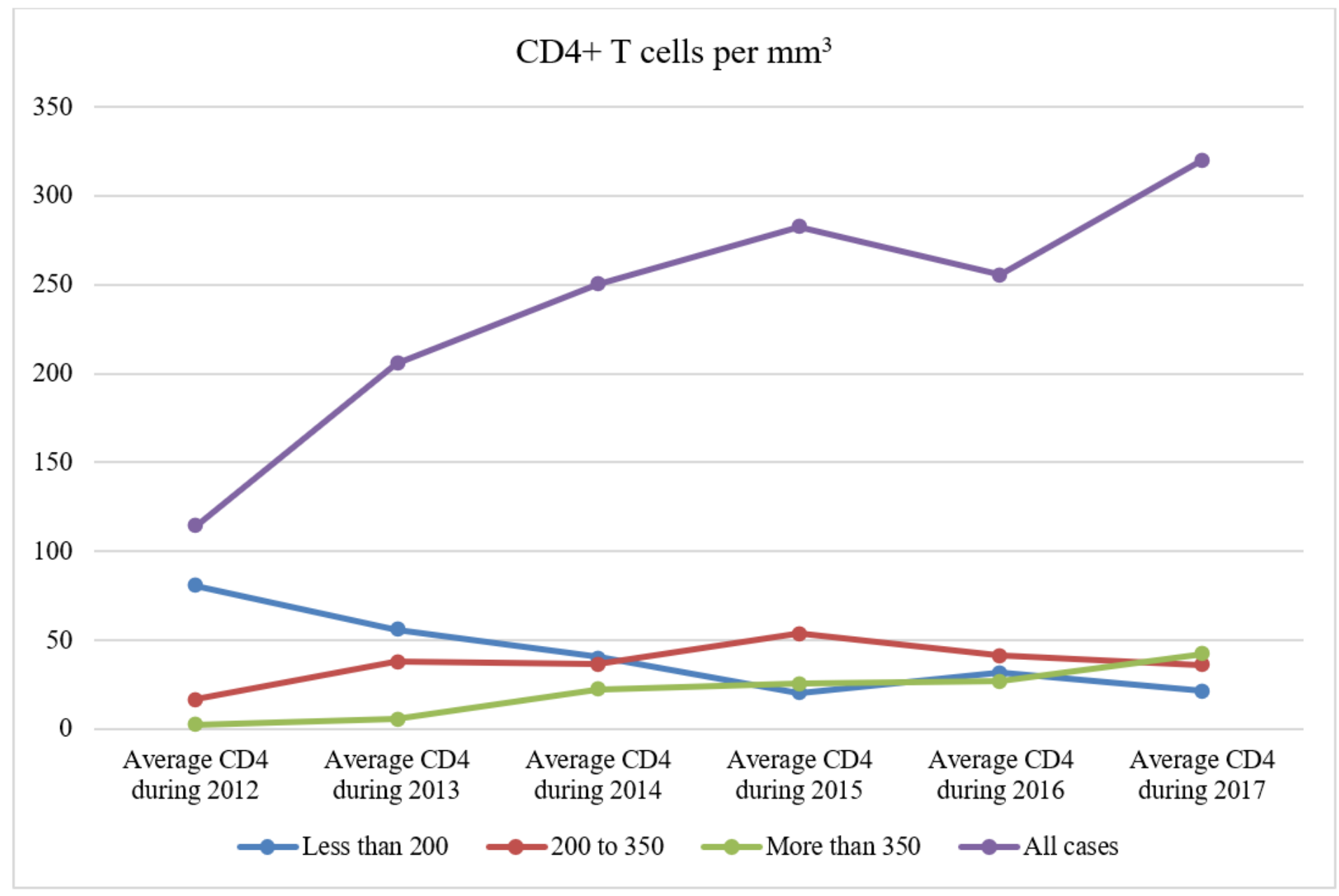

\section{Figure 3}

Trend of CD4+ T cells per millimeter cubic among TB/HIV co-infected patients in two governmental hospitals of Mekelle, Ethiopia, 2012-2017. 


\section{Survival function}

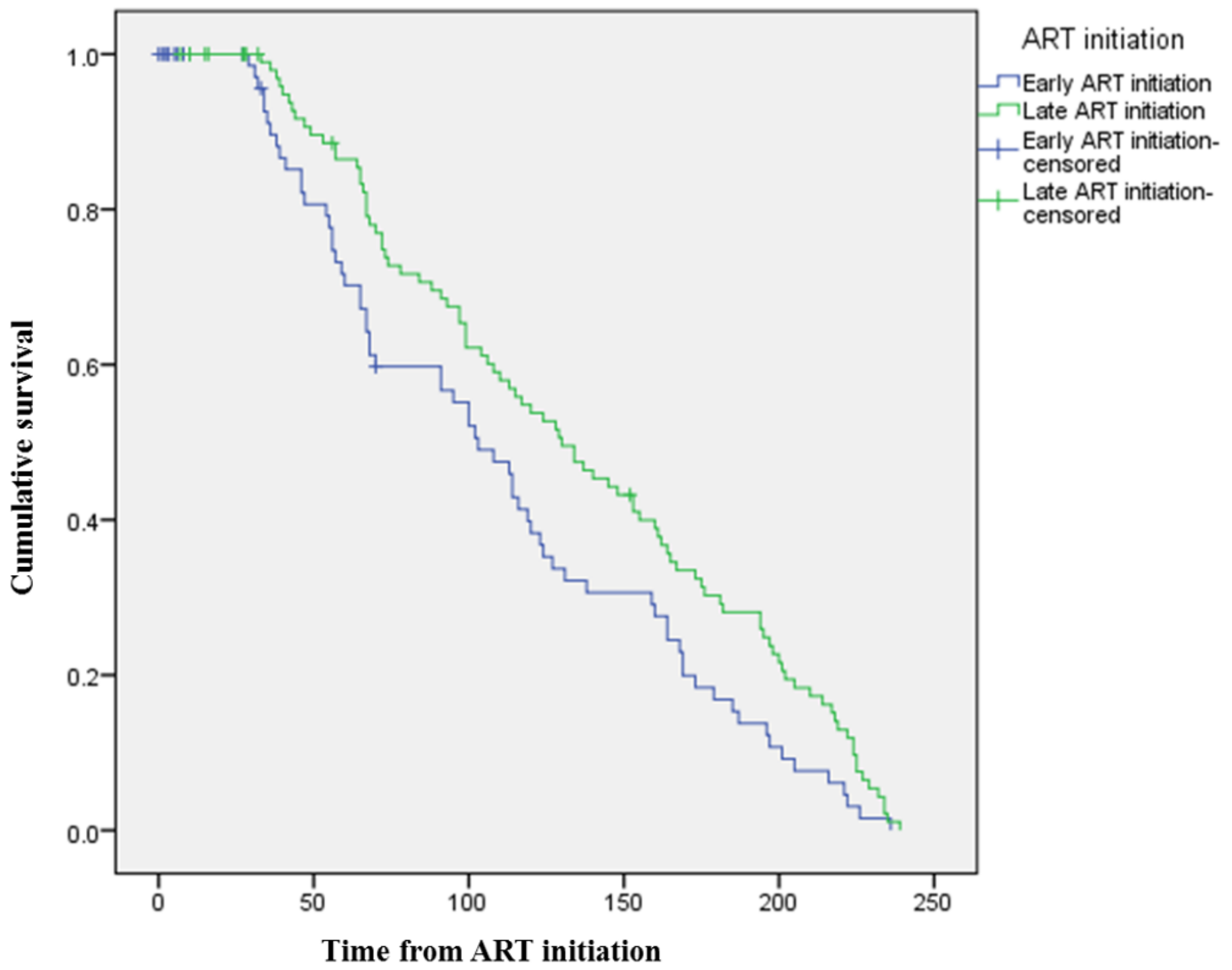

Figure 4

Comparison of survival status of early and late ART initiation among TB/HIV co-infected patients in two governmental hospitals of Mekelle, Ethiopia, 2012-2017.

\section{Supplementary Files}

This is a list of supplementary files associated with this preprint. Click to download.

- Appendix.docx 